\title{
Optimizing silviculture in mixed uneven-aged forests to increase the recruitment of browse-sensitive tree species without intervening in ungulate population
}

\author{
Andrej Ficko ${ }^{(1)}$, \\ Joerg Roessiger ${ }^{(2-3)}$, \\ Andrej Bončina ${ }^{(1)}$
}

\begin{abstract}
An increase in ungulate abundance in Europe in recent decades has raised concerns for the survival of browse-sensitive tree species in its early life history stages. A possible strategy for mitigating the browsing-induced mortality of natural regeneration is to optimize silviculture. We used matrix population models parameterized for three types of Abies alba - Picea abies - Fagus sylvatica forests $(3,183$ permanent sample plots from three study areas in Slovenia, 39,717 ha), and a non-linear optimization to: (i) schedule optimal timing and intensity of logging in the next 100 years to increase the recruitment of Abies alba without intervening in the population of ungulates; and (ii) examine the influence of different natural recruitment rates on the potential for mitigating recruitment failure through silviculture optimization. The optimal management has required species-, growth- and diameter-specific logging, including intensive logging of large-diameter Abies alba in the first decades and strict conservation of recruits. The potential for mitigating recruitment failure through optimization increased progressively with natural recruitment rate and progressively at a decreasing rate with time. Optimizing silviculture was effective for maintaining Abies alba in stands exposed to low or moderate browsing pressures. Faced with chronic ungulate herbivory, forest managers should primarily focus on the reduction of herbivory and to a lesser extent on optimizing silviculture.
\end{abstract}

Keywords: Continuous Cover Forestry, Optimization, Natural regeneration, Recruitment, Abies alba decline despite a reduction in browsing pressure (Tanentzap et al. 2011), because the relationship between ungulate density and their impact on regeneration is non-linear (Kuijper et al. 2009). Considering possible strategies for mitigating the excessive mortality of browse-sensitive species in its juvenile stages, it seems reasonable to adapt current forest management practices first and then optimize hunting strategies or change the silvicultural system. A major change of the silvicultural system may be ruled out as too adventurous since no empirical evidence on the effectiveness of such an action can be provided in a man-
(1) University of Ljubljana, Biotechnical Faculty, Department of Forestry and Renewable Forest Resources (Slovenia); (2) Institute of Forest Management, Department of Ecology and Ecosystem Management, Center of Life and Food Sciences Weihenstephan, Technische Universität München, Hans-Carl-von-Carlowitz-Platz 2, 85354 Freising (Germany); (3) National Forest Center - Forest Research Institute Zvolen, T. G. Masaryka 22, 96092 Zvolen (Slovakia)

@ Andrej Ficko (andrej.ficko@bf.uni-lj.si)

Received: Jul 27, 2017 - Accepted: Jan 12, 2018

Citation: Ficko A, Roessiger J, Bončina A (2018). Optimizing silviculture in mixed unevenaged forests to increase the recruitment of browse-sensitive tree species without intervening in ungulate population. iForest 11: 227-236. - doi: 10.3832/ifor2567-011 [online 2018-03-12]

Communicated by: Tomás Vrska ager's professional lifetime. Similarly, a drastic increase in culling is not likely to be adopted by hunters because of the economic considerations of hunting and a lack of hunters' motivation to harvest female deer (Milner et al. 2006).

There has been a continuous discussion between forest managers and game managers on the necessary measures for mitigating the decline of browse-sensitive species. A rather general conclusion has been that the survival of browse-sensitive species at an early stage can be influenced by appropriate forest management and adaptive game management (Reimoser \& Gossov 1996, Tremblay et al. 2007). However, practitioners need a clearer picture of how forest management should be adapted to compensate for the negative impact of ungulates on regeneration and recruitment.

Silvicultural systems are one of the main instruments for regulating tree species composition. In the clear cutting system with artificial regeneration, the composition and quality of the new crop is directly determined through the introduction of preferred native or exotic species or provenances (Mathews 1999). In continuous cover forestry (CCF) using natural regeneration, silvicultural treatments control competition between tree species for light, space, water and nutrients. In the absence 
of silvicultural treatments, competition and other factors such as catastrophic disturbances, seed predation, pathogens and ungulate herbivory may gradually lead to the dominance of more competitive species less impacted by these factors (Diaci et al. 2011, Kamler et al. 2016).

The search for silvicultural alternatives in forests with high levels of ungulate herbivory can be performed by Operations Research (OR) methods. Foresters have used OR methods for decades. Most of the studies in CCF applying OR methods have focused on financially optimal management or adapting business-as-usual timber production-oriented management to alternative scenarios that consider multiple objectives or constraints (Miina et al. 2010, López Torres et al. 2016). Optimization has also been used in several bioeconomic models to propose financially optimal management under the presence of factors that decrease economic returns, such as large-scale disturbances (Hyytiäinen \& Haight 2010), ungulates (Clasen et al. 2011), changing timber price and tree growth (Pukkala 2015) or climate change (Lafond et al. 2014). Optimization also proved to be useful for selecting the portfolio of tree species with the lowest risk (Griess \& Knoke 2013). However, optimization techniques have not been extensively used in silviculture and no attempts have been made to schedule scenarios that increase the proportion of browse-sensitive tree species in juvenile stages at a given browsing pressure. We identified Manso et al. (2014) as the only study that uses the optimization technique to evaluate the suitability of silvicultural alternatives for establishing natural regeneration in temperate forests. However, their study considers pure even-aged stands of a light-demanding species with no incidence of ungulate browsing. The need for simulation and optimization studies is also due to the lack of empirical evidence concerning how silviculture can mitigate the poor survival of trees until a certain age or diameter measurement threshold is reached (i.e., recruitment failure - Beguin et al. 2009, Kuijper et al. 2009, Miller et al. 2009). This is primarily due to the fact that large-scale experiments physically examining the effectiveness of alternative management regimes are too costly and time-consuming (Bettinger \& Chung 2004). Notwithstanding the superiority of empirical studies, simulation and optimization studies can support decision-making about the management of browse-sensitive species in mixed forests browsed by ungulates.

We used silver fir (Abies alba Mill.) as an example of a severely browsed tree species in Europe to show the optimal response of silviculture to recruitment failure and to explore the limits of silviculture under limited recruitment. A number of studies on regeneration and recruitment of silver fir in mixed forests showed that silver fir survival is dependent on multiple biotic, abiotic and anthropogenic factors, among which past stand management and ungulates play a significant role (Gill 2006). Large areas of Central European forests were profoundly changed in the $19^{\text {th }}$ and $20^{\text {th }}$ century, mostly due to the planting of commercially more valuable Norway spruce and overly simplified stand treatments (Ellenberg 1996). In the late $19^{\text {th }}$ century, some foresters (e.g., Gayer 1886) began to realize that the uniform treatment of mixed species forests disregards the ecology of tree species, and consequently they began practicing near-natural silvicultural systems. As an alternative to planting and uniform treatment of forest stands, a range of CCF systems were introduced and popularized throughout Europe. As a consequence of spontaneous recolonization, re-introductions and the lack of natural predators, the abundance of red deer (Cervus elaphus L.) and their geographical range in Europe has increased rapidly in recent decades (Milner et al. 2006, Gill 2006). Browsing by large herbivores has been shown to have detrimental effects on survival and recruitment of silver fir (Klopčič et al. 2010).

We used non-linear programming to propose the optimal timing and intensity of logging to increase the number of juvenile silver firs in mixed Norway spruce (Picea abies Karst.) - silver fir - European beech (Fagus sylvatica L.) forests managed under CCF with natural regeneration. We tested two hypotheses: (i) silviculture optimization can increase the number of juvenile silver firs even in forests suffering from poor recruitment without intervening in ungulate population; (ii) the potential for mitigating the recruitment failure of silver fir through silviculture optimization increases progressively with increasing recruitment rate.

\section{Materials and methods}

\section{Study areas}

We selected three study areas in Slovenia $(39,717$ ha - Fig. 1a) representing three major silver fir habitats in Central and Southeastern Europe (Ellenberg 1996). The study areas were located in the main red deer habitat areas in Slovenia (Fig. 1b) exhibiting contrasting browsing rates (Fig. 1c). The areas contrast with regard to recruitment rates of silver fir, climatic and edaphic conditions, and historical logging (Ficko et al. 2016). In all three study areas CCF (single tree selection, group selection or irregular shelterwood system) has been practiced for at least 50 years.

The study area no. 1 (15,023 ha) - Alpine mixed conifer and broad-leaved mountain forests on carbonate substrate (hereinafter Julian Alps) - was located in the Jelovica high mountain plateau. The parent material is limestone and dolomite, with rendzic leptosols (64\%) and molic leptosols (31\%) prevailing. The area is characterized by a typical mountain plateau climate (mean annual temperature of $5.4{ }^{\circ} \mathrm{C}$, mean annual precipitation of $2416 \mathrm{~mm}$ ), abundant regeneration and recruitment of silver fir and an average density of 8.1 red deer $\mathrm{km}^{-2}$ in the broader area. Forests regenerate well under a primarily irregular shelterwood system that has been practiced for the last six decades. Tree species composition was dominated by Norway spruce; the average standing volume equaled $349 \mathrm{~m}^{3}$ $\mathrm{ha}^{-1}$, of which Norway spruce and silver fir accounted for $78.1 \%$ and $11.9 \%$, respectively (Ficko et al. 2016). The diameter structure was J-shaped for all three main tree species (Fig. 2a). Business-As-Usual logging rates per dbh classes calculated for the period 2002-2013 are shown in Fig. 2b.

The study area no. 2 (5051 ha, hereinafter W. Dinarides) - mixed spruce-silver firbeech mountain forests from the Western Dinarides - were represented by the Sneznik and Leskova dolina forest management units. The study area is on a carbonate substrate with mostly chromic cambisols. It differs from the Alps with regard to orography, syntaxonomy and syndynamics (Ellenberg 1996). The W. Dinarides are characterized by the dominance of silver fir in the standing volume (57\%) with almost $60 \%$ of silver fir volume accumulated in silver firs with a diameter $\geq 50 \mathrm{~cm}$, high browsing rates and an average recruitment of only 0.5 silver firs ha ${ }^{-1}$ per year, due to an abundant red deer population with 12.8 animals $\mathrm{km}^{-2}$ in the broader area (Ficko et al. 2011). The current abundance of silver fir is a consequence of a period of intensive regeneration of these forests in the mid- $19^{\text {th }}$ century when red deer density was low (Klopčič et al. 2010), followed by single-tree selection forest management introduced in the late $19^{\text {th }}$ century and small-scale irregular shelterwood, group selection and single-tree selection management in recent decades. The diameter structure of silver fir deviated from the typical J-shaped curve (Fig. 2a) which can be attributed to limited recruitment of silver fir in relatively longer rotation periods in comparison to two other study areas. Business-As-Usual logging rates in W. Dinarides were comparatively lower to logging rates in the two other study areas (Fig. 2b).

The study area no. 3 (19,643 ha, hereinafter Pohorje) was selected to represent the most widespread type of silver fir forests in Europe - silver fir forests on sandy loams from silicate rocks where silver fir and Norway spruce co-dominate (Ellenberg 1996). The Pohorje Mountains are characterized by acid soils (mean pH 4.0), warmer climate (mean annual temperature $7.2{ }^{\circ} \mathrm{C}$ ), highly productive sites $\left(13.3 \mathrm{~m}^{3} \mathrm{ha}^{-1} \mathrm{yr}^{-1}\right)$, successful transition of early life stages of silver fir and average density of red deer of $3.7 \mathrm{~km}^{-2}$ (Ficko et al. 2011). During the last 50 years an irregular shelterwood silvicultural system has been practiced. Tree species composition in Pohorje was dominated by Norway spruce and silver fir; the average standing volume equaled $290 \mathrm{~m}^{3} \mathrm{ha}^{-1}$, 
Fig. 1 - (a) General location of the three study areas. (b) A kernel map of red deer densities in an around the study areas (adapted after Stergar et al. 2009). (c) Percentage of browsed regeneration in the height class 15-150 cm between 1996 and 2004 (Jerina 2009). (d) Map of the permanent sampling plots in the (1) Julian Alps ( $n=1556),(2)$ W. Dinarides $(n=$ 898) and (3) the Pohorje Mountains $(\mathrm{n}=729)$. (e) Pictures of the silver fir stands (photo: A. Poljanec and D. Rozenbergar).

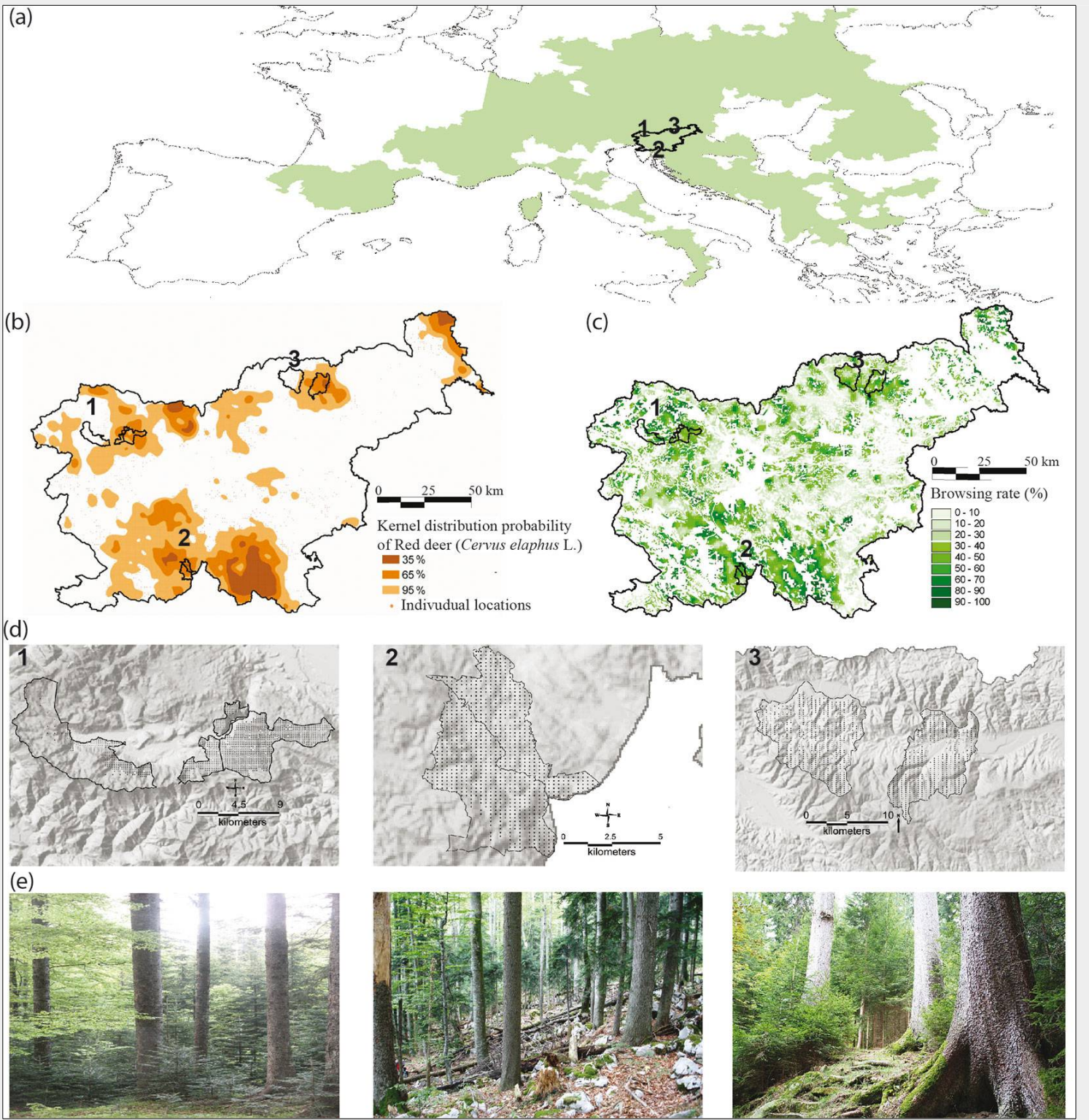

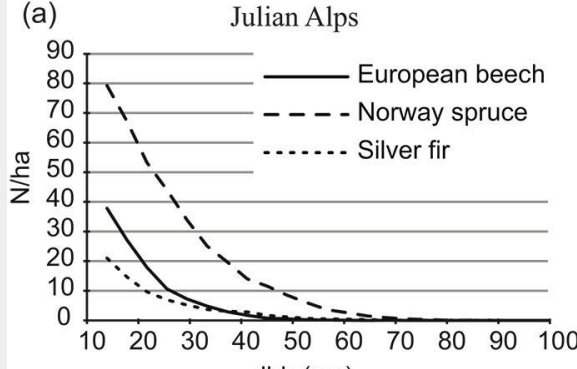

(b)

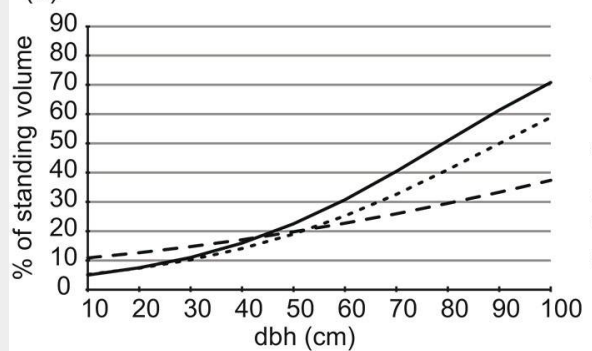

W. Dinarides
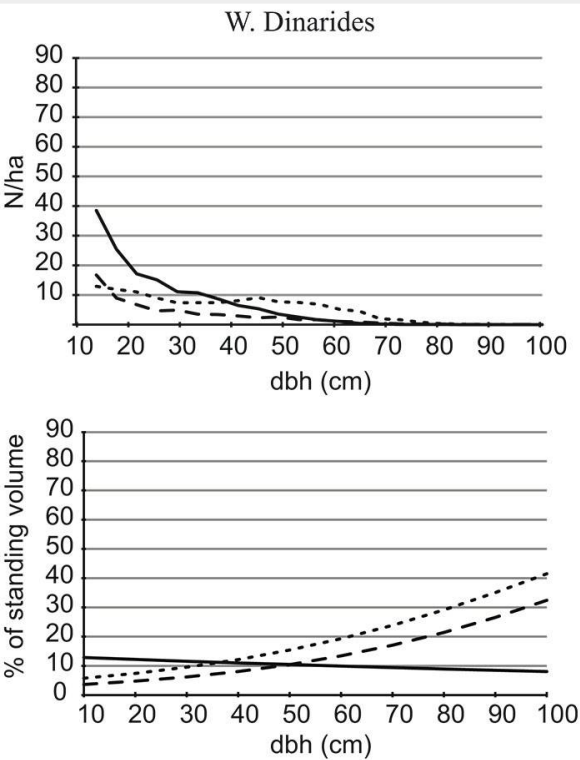

Fig. 2 - (a) Diameter at breast height distribution at the beginning of the simulation period. (b) Business-As-Usual logging rates cal culated for the period 2002-2013. 
of which Norway spruce and silver fir accounted for $56.0 \%$ and $35.5 \%$, respectively (Ficko et al. 2016). Business-As-Usual in the study area no. 3 was characterized by harvesting of approximately $11.0 \%$ of standing volume, mainly Norway spruce and silver fir in the dbh class $\geq 50 \mathrm{~cm}$ (Fig. 2b).

Details of Business-as-Usual for all three study areas are available in forest management plans for forest management units Jelovica and Notranji Bohinj (study area no. 1), Sneznik and Leskova dolina (study area no. 2) and Radlje-desni Breg and Lovrenc na Pohorju (study area no. 3-SFS 2017).

\section{Methods}

\section{Matrix transition model}

We used a density-dependent and growth variation-sensitive matrix population model originally developed for studying financially optimal selection logging of spruce, silver fir and beech in Illyrian mountainous beech forest in Dinarides (Roessiger et al. 2016). The model was later parameterized for Julian Alps and the Nemoral spruce forest in Pohorje with $65.4 \%-99.8 \%$ correct predictions of demographic processes (Ficko et al. 2016). These deterministic Markov chain models use tree species-specific and stand-density and dbh-dependent nonlinear functions for recruitment, transition and mortality, based on the observed vital rates from 3183 permanent sample plots and the salvage logging register (SFS 2014) in the period 2002-2013.

We defined recruitment rate as the number of trees added to the population by reaching the minimum diameter at breast height of $10 \mathrm{~cm}$ over a period of 10 years. The probability that a tree species $j$ recruits into a stand $\left(R_{\mathrm{i}}\right)$ was modelled as a function of stand basal area (ba) and respective mean $(\overline{b a})$ in each study area (eqn. 1). A hectare factor $(\mathrm{HF})$ of 50 was used to scale the recruitment on the plot level to the stand level. This two parametric ( $\alpha$ and $\beta$ ) log-logistic distribution accounted for the general rule that the number of recruits decreases with increasing stand density (Stancioiu \& O'Hara 2006), but it also considered that recruitment is possible only at a minimum stand density representing continuous cover of mature stands with seed trees (Amm et al. 2014). Such a function may be more realistic for shade tolerant species than commonly used functions for recruitment (Rämö \& Tahvonen 2014), which assume a monotonous decrease of recruitment with increasing ba, implying that maximum recruitment occurs on bare land. Using a dispersal recruitment model, Amm et al. (2014) showed that silver fir seed dispersal occurs at shorter distances from seed trees than previously thought, indicating that sufficient stand density should be maintained for successful recruitment (eqn. 1):

$$
R_{j}=\frac{\alpha \beta\left(\frac{b a}{\overline{b a}} \frac{\pi}{\beta \sin (\pi / \beta)}\right)^{(\beta-1)}}{\left[1+\left(\frac{b a}{\overline{b a}} \frac{\pi}{\beta \sin (\pi / \beta)}\right)^{\beta}\right]^{2}} H F
$$

To account for variable growth of individual trees in uneven-aged forests, we followed the approach of Roessiger et al. (2016) who modelled stand development using three growth classes (slow, mediumand fast-growing trees). The recruits were allocated into one of the three growth classes by a function that considered the stand density $(\mathrm{ba})$ and their diameter (dbh - eqn. 2). The probability $M C_{i j}$ that a recruit of the $j$-th species was a member of the growth class $i$ was calculated as the quotient $p_{\mathrm{ij}}$ (eqn. 3):

$$
\begin{aligned}
& M C_{i j}=\exp ^{\left(u_{i j}+v_{i j} d b h_{12}+w_{i j} b a_{t-10}\right)} \\
& p_{i j}=\frac{M C_{i j}}{\sum_{i=1}^{3} M C_{i j}}
\end{aligned}
$$

Tree species populations were divided

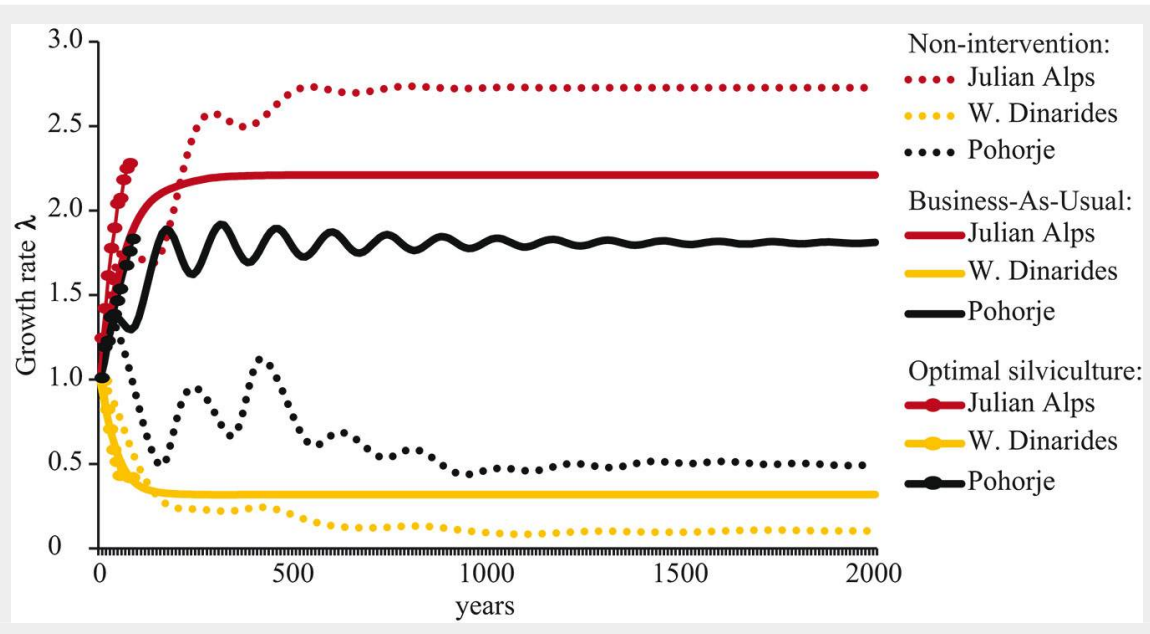

Fig. 3 - The projection of silver fir population growth rate $(\lambda$, base $=$ year 0$)$ under Busi ness-As-Usual and Non-intervention management regimes until the equilibrium is reached. Plotted also growth rate under 100 years of optimal silviculture. into 23 diameter classes each $4 \mathrm{~cm}$ wide corresponding to the range of measured $\mathrm{dbh}$. The smallest dbh class thus included all trees with $\mathrm{dbh} \in[10,14) \mathrm{cm}$, and the largest dbh size class included all trees with dbh larger or equal to $98 \mathrm{~cm}$. The probability $T_{i j k}$ for transition of a tree of the $j$-th species and the $i$-th growth class to grow from the $(k-1)$-th to the $k$-th dbh class in 10 years, was calculated as the sum of constant transition probability $\left(\mathrm{Mi}_{\mathrm{ij}}\right)$, obtained from the mean increment of each growth class (the first summand in eqn. 4), and variable transition probability calculated by logistic regression using $d b h$ and stand density (ba) as predictors (the second summand in eqn. 4 ):

$T_{i j k}=\frac{M I_{i j}-0.5}{4}+\frac{\left(1+\exp ^{\left.-\left(u+v d b h_{d-4}+w \cdot b a_{t-10}\right)\right)^{-1}}\right.}{4}$

where $u, v$ and $w$ are the coefficients for the intercept, the mean of the (k-1)-th or $(k-2)$-th $d b h$ class $\left(d b h_{d-4}\right.$ or $d b h_{d-8}$, in $\left.\mathrm{cm}\right)$ and the $i$-th growth class, and the $b a$ in the $t-10$ period $\left(b_{t-10}\right.$, in $\mathrm{m}^{2}$ ha-1), respectively.

The mortality probability of the $j$-th species $\left(M_{\mathrm{j}}\right)$, defined as the proportion of trees in a given dbh class that die in 10 years, was calculated by logistic regression using $d b h$ as a regressor (eqn. 5):

$$
M_{j}=\frac{1}{1+\exp ^{(u+v \cdot d b h)}}
$$

All parameters for the equations and model fit statistics are available in Ficko et al. (2016).

The matrix model projections of silver fir population growth rate $(\lambda$, base $=$ year 0$)$ under Business-As-Usual and Non-intervention management regimes can be seen in Fig. 3.

\section{Optimization of silviculture}

As an alternative to Business-As-Usual (BAU) management, we searched for the optimal sequence and intensity of selective logging to create stand densities at which the recruitment of silver fir is maximal. Bearing in mind that silver fir is a shade-tolerant species which regenerates when the micro-site conditions become favorable (Dobrowolska \& Veblen 2008), that it grows well for decades in sufficiently humid conditions under dispersed light, and that it maintains strong recovery potential after suppression, we tried to approximate such conditions in our model. A good proxy indicator of light and humidity in an uneven-aged forest is stand density, measured by stand basal area (Wagner et al. 2011). By keeping stand basal area close to the level optimal for the recruitment of silver fir while regulating the competition of other trees through diversified harvesting, we aimed to increase the number of recruited silver firs. The objective function to be maximized was the mean number of silver firs in the diameter class $10-14 \mathrm{~cm}$ $\left(n_{d b h=12}\right)$ over a period $(t)$ of 100 years (eqn. 6): 


$$
\max \frac{\sum_{t=0}^{100} n_{d b h=12}}{10}
$$

The optimal sequence and intensity of harvesting was determined by non-linear optimization in the What's Best ${ }^{\circledast}$ package 12 (Lindo Systems Inc 2012). The nonlinear solver uses a generalized reduced gradient algorithm which uses linear approximations to the problem functions at a number of stages in the solution process. The time step considered was fixed at 10 years which is the usual planning period in the area, and the simulation period was 100 years. Except for the resource limitation constraint (i.e., logging in a period should not exceed the standing volume), we did not impose any constraints in the model.

\section{Sensitivity analysis}

To test the hypothesis that the potential for mitigating the recruitment failure of silver fir through optimization increases progressively with increasing recruitment rate, we performed a sensitivity analysis of the objective function in the W. Dinarides. The W. Dinarides represent an empirical example of forests with extremely low recruitment (Ficko et al. 2011). By gradually increasing the current recruitment rate in the $W$. Dinarides to the rates in the other two study areas while repeatedly optimizing the management, we examined the response of the objective function in the optimization. The value of the objective function after optimization was then compared to its value under BAU. Moreover, we compared the temporal effectiveness of the optimized silviculture with that of BAU. We compared the number of silver firs in the diameter class $10-14 \mathrm{~cm}$ before and after optimization by decade at the current recruitment rate and at a rate which is 10times higher than the current one to see how fast the optimization can reverse the negative population trend of silver fir.

\section{Results}

Optimal timing and intensity of logging Optimal timing and intensity of logging in the study areas depended on the initial state, the projected dynamics of tree species composition and recruitment rate. To increase the recruitment of silver fir, more intensive logging is needed in all case study areas (Fig. 4), particularly in the first three to four decades, followed by a period of moderate logging (Fig. 5). However, the temporal distribution and intensity of logging differed substantially among the study areas with regard to dbh classes and tree species.

In the Julian Alps more intensive logging of medium-diameter trees in comparison to 100 years of BAU is needed, particularly for spruce (Fig. 4). The optimal scenario would be the following: intensive harvesting in the first 30 years (Fig. 5, left panels) would cause excessive regeneration of

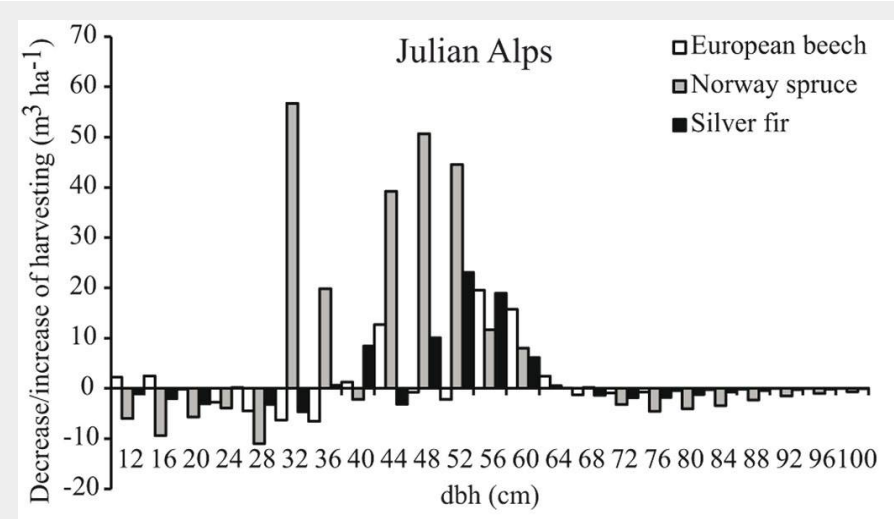

Fig. 4 - Cumulative changes required in $\mathrm{BAU}$ over 100 years to increase the recruitment of fir.
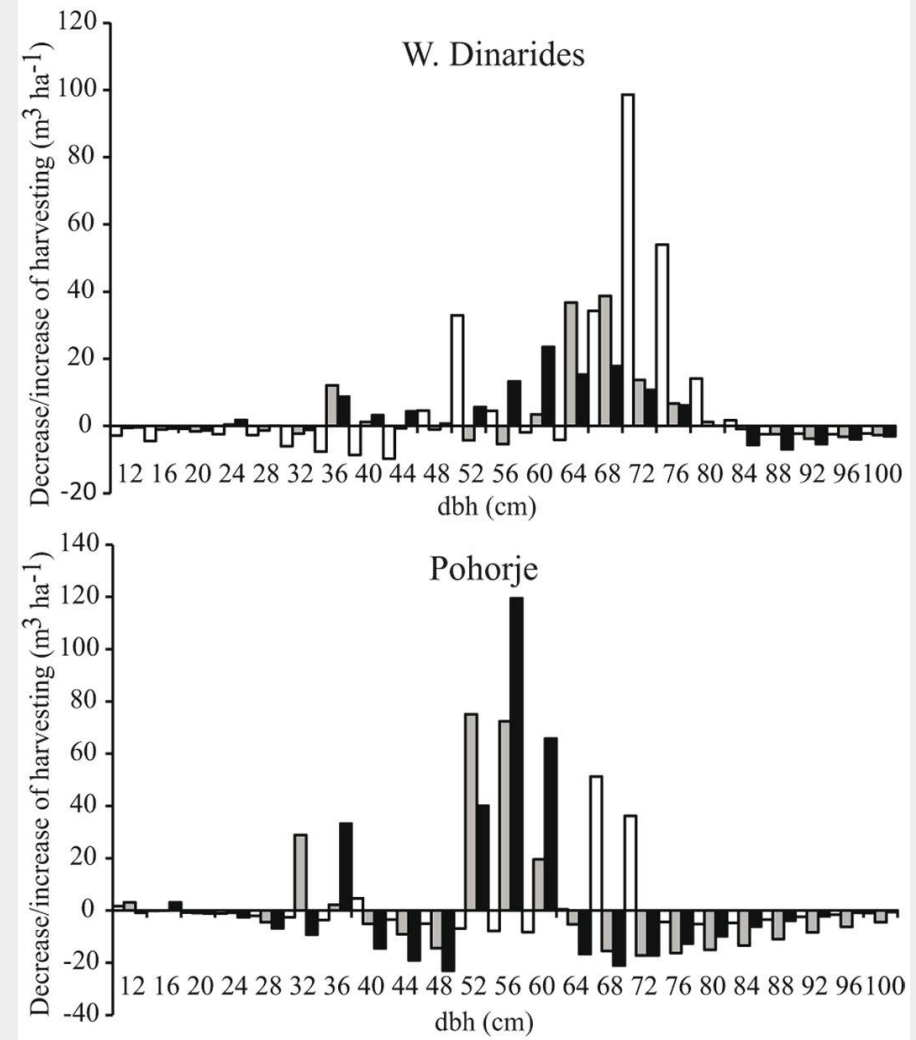

beech, spruce and silver fir. Due to the competitive recruitment of silver fir versus that of the other tree species and continuous targeted harvesting, a bimodal distribution of standing volume would appear in the following decades, with one peak representing a population of medium $\mathrm{dbh}$ and the second peak representing large dbh individuals. From the year 30 onwards, logging should be concentrated on large-diameter trees to maintain the optimal stand density. Towards the end of the 100-year period, logging trees smaller than $50 \mathrm{~cm}$ would lead to a dbh structure with smaller diameters and standing volume accumulated in the small and medium-diameter trees (Fig. 5, lower leftmost panel). The diameter distribution of forests and silver fir population after 100 years of optimized silviculture would be positively skewed, which indicates that the optimized silviculture is clearly superior over BAU in increasing the number of juvenile silver firs (Fig. 6 , Tab. 1).

Silviculture optimal for recruitment of sil- ver fir in the W. Dinarides required more intensive logging of large-diameter trees (50 $\mathrm{cm} \leq \mathrm{dbh}<82 \mathrm{~cm}$ ), while keeping trees with a $\mathrm{dbh} \geq 82 \mathrm{~cm}$ in the forest for seed production and stand density maintenance (Fig. 3). Intensive logging mostly refers to large-diameter silver firs in the first 40 years (Fig. 5, middle panels) which should be replaced in the next 20 years with moderate logging distributed across the population. After 60 years of moderate interventions silver fir should be almost completely exempt from logging, which should concentrate mainly on beech to regulate its competitiveness versus silver fir. The model suggests that intensive logging of large-diameter trees at the beginning together with the total conservation of ingrown silver fir would partially compensate for the disproportionally low natural recruitment of silver fir in comparison to that of spruce and beech. The optimization will change the diameter distribution of forests but will have no major positive long-term effect on the silver fir population (Fig. 6). 

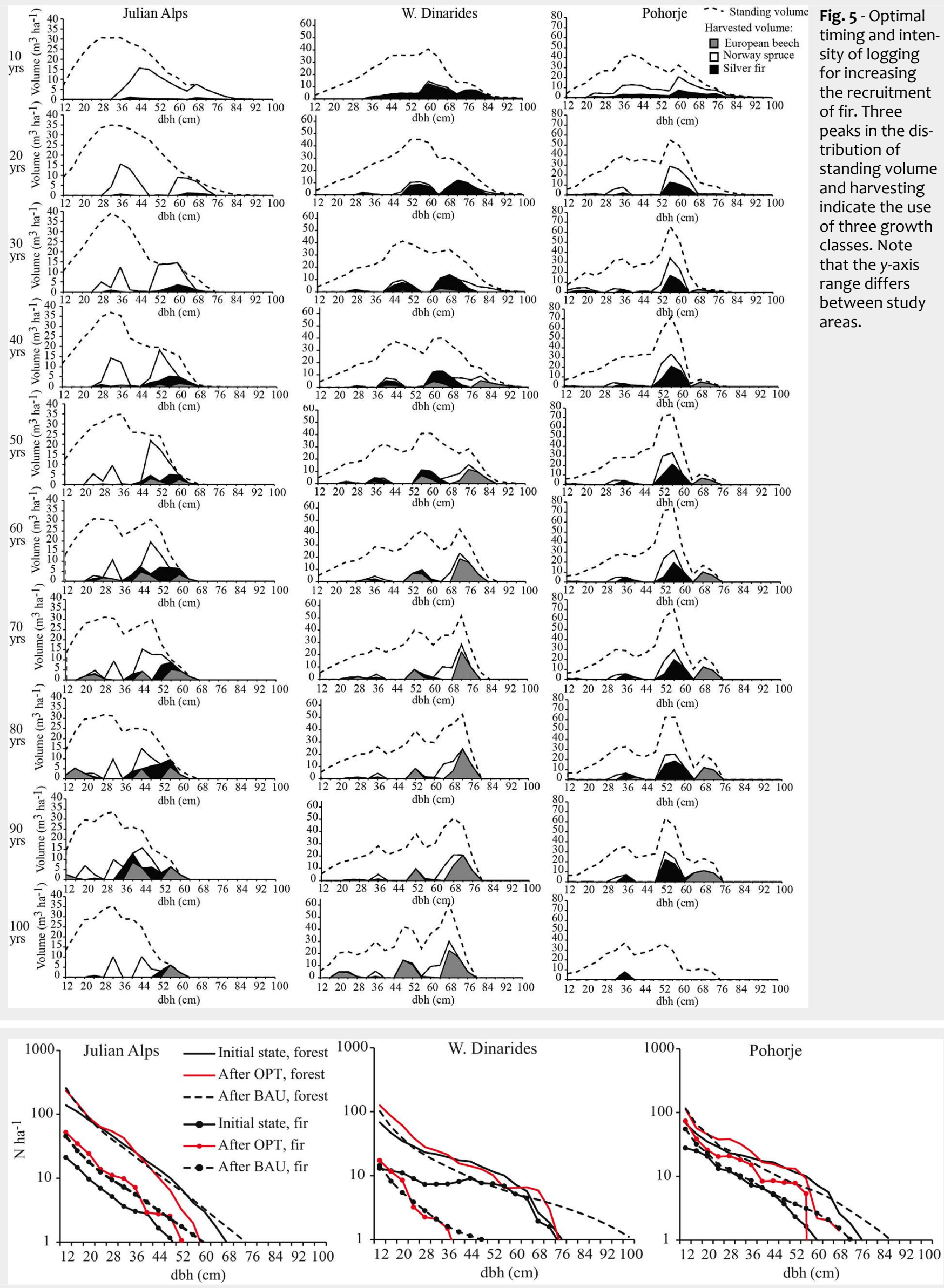

Fig. 6 - The diameter distribution of forests and fir in three study areas before and after 100 years of optimal silviculture (OPT) and Business-As-Usual management (BAU). Logarithmic scale with base 10 is used for $y$-axis. 
The proportion of large-diameter silver firs is expected to significantly decrease and the proportion of small-diameter silver firs is expected to significantly increase (Tab. 1).

In Pohorje the optimization required intensive logging of large diameter silver firs, spruce and beech, while silver firs and spruce above and below $50-60 \mathrm{~cm}$, and beech above and below $68-72 \mathrm{~cm} \mathrm{dbh}$, should be logged much less intensively (Fig. 4). The optimal logging should begin with a decade of intensive interventions in all dbh classes and species, and continue with 40 years of logging only large-diameter trees with dbh $50-70 \mathrm{~cm}$, mostly silver fir (Fig. 5, left panels). This would result in an increased standing volume of mediumdiameter trees. In the period from 60-100 years, beech should become the primary target of logging; in the dbh class 58-62 $\mathrm{cm}$, approximately $40 \%$ of its standing volume should be cut, as well as all beech larger than $62 \mathrm{~cm}$ in $\mathrm{dbh}$. Similar to the J. Alps, optimization in Pohorje increased the number of small- and medium-diameter silver firs (Fig. 6), although at an insignificant rate (Tab. 1).

\section{Optimization as a tool to mitigate recruitment failure}

In the previous sections we showed that management optimization can increase the number of juvenile silver firs in forests suffering from recruitment failure even at very low recruitment rates. By optimizing management, the number of juvenile silver firs can always be increased faster than in non-optimized management (Fig. 7a). However, the effectiveness of optimization proved to be highly dependent on recruitment rates. If the recruitment in the $\mathrm{W}$. Dinarides were higher, the superiority of optimized silviculture over BAU would be disproportionally higher as evidenced by the steeper slope of the OPT curve in Fig. 7a. For instance, if the natural recruitment
Tab. 1 - Growing stock $\left(\mathrm{m}^{3} \mathrm{ha}^{-1}\right)$ of fir in dbh classes $10-29 \mathrm{~cm}, 30-49 \mathrm{~cm}$, and $\geq 50 \mathrm{~cm}$ before and after 100 years of optimal silviculture (OPT) and Business-As-Usual management $(\mathrm{BAU}) .(*, * *, * *)$ : denotes significance of the two-tailed $z$-test for the proportion of growing stock of fir in dbh classes $10-29 \mathrm{~cm}, 30-49 \mathrm{~cm}$, and $\geq 50 \mathrm{~cm}$ after 100 years of OPT or BAU being significantly different from its initial proportion at $p \leq 0.05$, $\mathrm{p} \leq 0.01$, and $\mathrm{p} \leq 0.001$, respectively.

\begin{tabular}{llccc}
\hline Area & dbh class & Initial state & After OPT & After BAU \\
\hline J. Alps & $10-29 \mathrm{~cm}$ & 13 & 29 & 24 \\
& $30-49 \mathrm{~cm}$ & 18 & 36 & 33 \\
& $\geq 50 \mathrm{~cm}$ & 7 & $3^{*}$ & 25 \\
\multirow{4}{*}{ W. Dinarides } & Total & 38 & 68 & 83 \\
& $10-29 \mathrm{~cm}$ & 14 & $8^{* * *}$ & $7^{*}$ \\
& $30-49 \mathrm{~cm}$ & 66 & 6 & 11 \\
& $\geq 50 \mathrm{~cm}$ & 118 & $3^{* * *}$ & 24 \\
Pohorje & Total & 199 & 17 & 42 \\
& $10-29 \mathrm{~cm}$ & 26 & 42 & 31 \\
& $30-49 \mathrm{~cm}$ & 49 & 89 & $54^{*}$ \\
& $\geq 50 \mathrm{~cm}$ & 27 & 42 & $70^{* *}$ \\
& Total & 103 & 173 & 155 \\
\hline
\end{tabular}

were six-times the current rate, optimized management could increase the number of juvenile silver firs on average 2.6 times more than at the current recruitment rate.

Recruitment rate also play an important role in the time needed to compensate for recruitment failure. In forests with no recruitment limitation, the potential for improving silver fir demography through management optimization increases steeply in the first decades, but levels off later (Fig. 7b, upper lines). The temporal effectiveness of BAU for increasing the number of juvenile silver firs in forests with no recruitment limitation is much weaker. However, in recruitment-limited forests (Fig. $7 \mathrm{~b}$, bottom lines), BAU can be considered as a near-optimal solution since the number of recruited silver firs after optimization does not differ much from that prior to optimizing, indicating that extremely low recruitment ( $<1$ silver fir ha ${ }^{-1}$ year ${ }^{-1}$ ) cannot be mitigated by silviculture optimization.

\section{Discussion}

\section{Implications for silviculture and} ungulate management

The problem of how to optimally manage uneven-aged forests with poor recruitment has been considered for a long time (Sage et al. 2003, Didion et al. 2011). An increase in red deer abundance and their geographical range in Europe in recent decades (Milner et al. 2006, Gill 2006) has raised concerns about the conservation prospects of browse-sensitive species such as silver silver fir. While silver fir regeneration and recruitment has already been secured in some forests with high browsing pressure (Möst et al. 2015), many foresters are still faced with recruitment failure. This study agement regimes optimal for increasing the recruitment of silver fir without intervening in ungulate population. The advantage of Markov chain models is that stand used Markov chain models to present man-
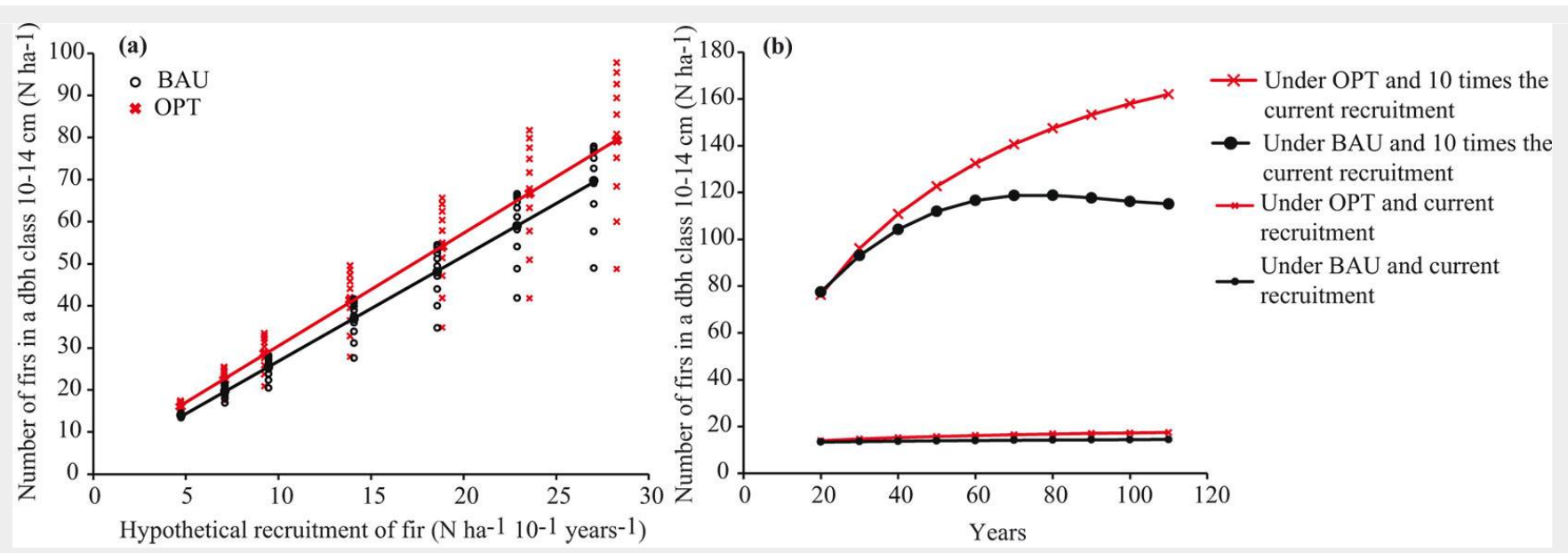

Fig. 7 - The effectiveness of management optimization for mitigating the recruitment failure of fir in the W. Dinarides. (a) The aver age number of juvenile firs in the population after 100 years of forest management optimized for recruitment and Business-AsUsual management at different recruitment rates. (b) Temporal effectiveness of optimized vs. BAU management in increasing the number of juvenile firs for two contrasting recruitment rates. 
structure and composition at the beginning of the simulation does not determine the development trajectory. Under the assumption of fixed vital rates, the asymptotic growth rate is the dominant (largest) eigenvalue of the population transition matrix. The asymptotic growth (Fig. 3) in each of the study areas was thus entirely dependent on transition matrices obtained by observing vital rates in the areas and not by the stand structure and composition at the beginning of the simulation.

We showed that higher recruitment can be achieved through repetitive intensive regeneration fellings followed by a series of species-specific selection fellings. The proposed management regimes are in line with empirical studies of silver fir growth under changing environmental conditions. Kupferschmid et al. (2013) for instance showed that by opening the canopy, favorable conditions for regeneration, faster growth of silver fir saplings and the transition of recruits into the upper canopy layer can be expected. Similar to our projection, De Andrés et al. (2014) detected the highly positive effect of canopy openness for silver fir seedling establishment and growth, interpreting it as the need for some radiation to maintain positive carbon balance once seed reserves run out. A study of photosynthesis response of Dinaric silver firs to different light and $\mathrm{CO}_{2}$ regimes under single-tree and group selection systems (Čater \& Levanič 2013) suggests that more intensive opening on sites with the single tree selection system is beneficial to silver fir as long as the uneven-aged stand structure is maintained. Our optimization study corroborates the general recommendation that reducing average growing stock and increasing tree species richness and structural diversity enhances the resilience of uneven-aged forests managed by close-tonature silviculture (Brang et al. 2014).

Intensive canopy opening proposed by the model may also have drawbacks. In addition to possibly decreasing stand stability intense regeneration fellings in the first decades may increase the patchiness of forest and thus offer more light for herb and shrub layers, possibly attracting ungulates. Several studies (Reimoser \& Gossov 1996, Kuijper et al. 2009) showed that ungulates preferentially forage in forest gaps. Among ungulates red deer shows the strongest preference for gaps with the longest duration of visits in gaps (Kuijper et al. 2009). A possible increase of browsing rate in gaps is likely to be particularly detrimental for recruitment in the W. Dinarides, where optimization proved to be least efficient. Moreover, an open canopy in combination with an admixture of lightdemanding and less palatable tree species may have an additive influence on silver fir browsing rate since palatable species are more at risk of being browsed among nonpalatable species (Miller et al. 2009). However, our results suggest that the possible effect of canopy openness on higher browsing rates may be to some extent compensated by decades of optimized logging, as long as species recruitment is above the level at which the population can be maintained. Ficko et al. (2016) showed that at the current recruitment rate, the silver fir population in the W. Dinarides would need a period far longer than the average lifetime of a fructifying silver fir to replace itself and that forest management optimal for silver fir recruitment could shorten the replacement period only negligibly. The ineffectiveness of management optimization for preserving silver fir in forests chronically suffering from limited recruitment is also due to the higher competitiveness of spruce and beech compared to that of silver fir at increased levels of light and nutrients in forest gaps. If the silver fir recruitment in the W. Dinarides were higher, a disproportionately higher number of small-diameter silver firs could be achieved by optimization without intervening in ungulate population management (Fig. 7a). More important information for practitioners is that the effect of management optimization on the number of silver firs is non-linear (Fig. 7b); all silver firs additionally ingrown under optimized silviculture in the first decades could be preserved and preferentially tended in the following decades to reach the upper canopy as soon as possible and begin to fructify. This leads us to the conclusion that silviculture optimization can contribute greatly to maintaining browsesensitive species in mixed forests also without intervening in ungulate population management as long as the recruitment is not a limiting factor.

\section{Operational implications}

Interpretation of optimization results from the point of practical forestry requires careful consideration. First, our model still did not account for the fact that some areas within the forest are probably more exposed to stressors (cf. Fig. 1c). Namely, several factors which influence the establishment of tree seedlings were not included in the model, e.g., site features (Ameztegui \& Coll 2015), tree fertility and dispersal (Amm et al. 2014). Stochastic modeling and optimization can partially decrease the uncertainty associated with the response of a forest to silvicultural treatments (Manso et al. 2014, Pukkala 2015). Another disadvantage of our optimization was that the impact of ungulates was not directly incorporated into modelling, meaning that scientific evidence on the effectiveness of silviculture for silver fir conservation versus ungulate population control is only deductive. However, the relationship between forest management, ungulates and natural regeneration has been quantified in spatially-explicit processbased models (Kramer et al. 2006) or gap models (Didion et al. 2011). A noticeable shortcoming of these models is that they do not optimize forest management or game culling simultaneously with modelling to optimally distribute the burden of tree species conservation between silviculture and game management.

Second, our optimization does not provide the answer on the optimal spatial distribution and size of the gaps (Muscolo et al. 2017). Although in CCF logging and regeneration is distributed continuously over the whole area, the horizontal structure of uneven-aged forests may differ significantly as a result of the silvicultural system applied (Mathews 1999). In practice, silvicultural decisions in uneven-aged forests are usually taken at the stand, cohort, tree group or tree level. Spatially-explicit individual tree models can help making more detailed predictions about growth of seedlings, saplings and adult trees under various light levels and types of partial cutting (Coates et al. 2003), but cannot provide with an optimal sequence of silvicultural measures unless coupled with an optimizer. To reach the value of the objective function from the non-spatial optimization, several approaches are possible in practice. For instance, spatial harvesting can be defined as an inverse combinatorial optimization problem. The idea of inverse optimization in this case would be to find values of logging intensities in a spatially explicit unit (e.g., forest stand or compartment), per tree species, growth and dbh class, which yields minimal adjustment of the value of the objective function obtained in the nonspatial optimization. This approach might be computationally demanding but also problematic from the perspective of data availability. Stand or compartment level data on recruitment, growth and mortality in uneven-aged forests are usually not available or are even missing in typical single-tree selection forests.

An alternative approach to planning the spatial distribution of management activities could be a single-step optimization, in which data from a permanent sampling plot grid would be used to pixelate uneven-aged forests into several components (pixels) and conduct the simulation and optimization simultaneously on the pixel level using simulated annealing or other metaheuristics (Bettinger et al. 2002). Another possible solution for conducting optimized logging in practice would be to implement second-level optimization, where the value of the objective function from the non-spatial optimization would be set as a constraint, and the objective function at the second-level optimization would be an ordinary cost function, e.g., minimum harvesting costs or maximum distances between harvested stands to increase the structural complexity of a forest. Clearly, a range of additional constraints can be set in the second-level optimization to assure the minimum impact of harvesting on a large scale.

So far, tree-level harvest optimization in uneven-aged forests has been conducted only in experimental plots where tree loca- 
tions have previously been recorded (Bettinger \& Tang 2015). Precision forestry offers new opportunities for making simultaneous optimization possible even at the tree level (Holopainen et al. 2014). By combining airborne laser scanning with terrestrial or mobile laser scanning or by mapping trees with sensors mounted on logging machines, accurate tree maps with attribute information can be derived (Holopainen et al. 2014) and later used in spatial optimization. Since both silver fir regeneration and foraging behavior of ungulates is micro-site dependent, high-resolution information is indispensable for better managing silver fir-ungulates trade-offs with operational research methods.

\section{Conclusions}

We showed how silviculture in mixed forests suffering from poor recruitment should be performed to increase the number of juvenile individuals. The optimal measures included tree species-, growthand diameter-dependent logging distributed over 100 years, including intensive logging of large-diameter trees in the first decades and strict conservation of immigrated recruits. It should be noted that silvicultural measures in practice might deviate from the optimal scenario prescribed here as a result of changed trophic interactions due to climate warming. We showed that the potential for increasing the number of juvenile trees with silviculture optimization is highly dependent on the natural recruitment rate. When the recruitment is low, Business-As-Usual CCF is already near-optimal. This implies that if survival of browse-sensitive species were higher, the capacity of silviculture for influencing longterm stand dynamics would be incomparably higher and not simplified only to regulating competition between two species (spruce and beech) which need less tending in their transition to upper storey. This simulation and optimization study indicates that recruitment rates of browse-sensitive and shade-tolerant species should not be allowed to drop below the "point of no return", where management optimization has no more room to compensate for their excessive mortality in juvenile stages. As the recruitment increases, optimized silviculture is becoming a progressively preferential option for increasing the number juvenile trees, particularly in the first decades, but less so in the following decades which calls for a rapid response. We conclude that silviculture of browse-sensitive and shade-tolerant species is worth of optimizing at low to moderate browsing pressures. However, faced with the threat of chronic ungulate herbivory and recruitment failure, forest managers should focus more on the reduction of herbivory than on optimizing silviculture.

\section{Acknowledgements}

This research was financially supported by the ARANGE project within the Euro- pean Commission's $7^{\text {th }}$ Framework Program (grant agreement no. 289437). AF acknowledges the financial support by Pahernik Foundation. The authors thank the Slovenian Forest Service for valuable inventory data.

\section{References}

Ameztegui A, Coll L (2015). Herbivory and seedling establishment in Pyrenean forests: influence of micro- and meso-habitat factors on browsing pressure. Forest Ecology and Management 342: 103-111. - doi: 10.1016/j.foreco.201 5.01.021

Amm A, Pichot C, Dreyfus P, Davi H, Fady B (2014). Improving the estimation of landscape scale seed dispersal by integrating seedling recruitment. Annals of Forest Science 69: 845856. - doi: 10.1007/s13595-012-0208-1

Beguin J, Pothier D, Prevost M (2009). Can the impact of deer browsing on tree regeneration be mitigated by shelterwood cutting and strip clearcutting? Forest Ecology and Management 257: 38-45. - doi: 10.1016/j.foreco.2008.08.013

Beschta RL, Painter LE, Levi T, Ripple WJ (2016). Long-term aspen dynamics, trophic cascades, and climate in northern Yellowstone National Park. Canadian Journal of Forest Research 46: 548-556. - doi: 10.1139/cjfr-2015-0301

Bettinger P, Graetz D, Boston K, Sessions J, Chung W (2002). Eight heuristic planning techniques applied to three increasingly difficult wildlife planning problems. Silva Fennica 36: 561-584. - doi: 10.14214/sf.545

Bettinger P, Chung W (2004). The key literature of, and trends in, forest-level management planning in North America, 1950 - 2001. International Forestry Review 6: 40-50. - doi: 10.1505/ ifor.6.1.40.32061

Bettinger P, Tang M (2015). Tree-level harvest optimization for structure-based forest management based on the species mingling index. Forests 6: 1121-1144. - doi: 10.339o/f6041121

Brang P, Spathelf P, Larsen JB, Bauhus J, Bončina A, Chauvin C, Drössler L, García-Güemes C, Heiri C, Kerr G (2014). Suitability of close-tonature silviculture for adapting temperate European forests to climate change. Forestry 87 : 492-503. - doi: 10.1093/forestry/cpuo18

Clasen C, Griess VC, Knoke T (2011). Financial consequences of losing admixed tree species: a new approach to value increased financial risks by ungulate browsing. Forest Policy and Economics 13: 503-511. - doi: 10.1016/j.forpol.2011. 05.005

Coates KD, Canham CD, Beaudet M, Sachs DL, Messier C (2003). Use of a spatially explicit individual-tree model (SORTIE/BC) to explore the implications of patchiness in structurally complex forests. Forest Ecology and Management 186: 297-310. - doi: 10.1016/S0378-1127(03)00301-

Côté SD, Rooney TP, Tremblay J-P, Dussault C, Waller DM (2004). Ecological impacts of deer overabundance. Annual Review of Ecology, Evolution and Systematics 35: 113-147. - doi: 10.1146/annurev.ecolsys.35.021103.105725

Čater M, Levanič T (2013). Response of Fagus sylvatica $\mathrm{L}$. and Abies alba Mill. in different silvicultural systems of the high Dinaric karst. Forest Ecology and Management 289: 278-288. - doi: 10.1016/j.foreco.2012.10.021

De Andrés EG, Camarero JJ, Martínez I, Coll L (2014). Uncoupled spatiotemporal patterns of seed dispersal and regeneration in Pyrenean silver fir populations. Forest Ecology and Management 319: 18-28. - doi: 10.1016/j.foreco.2014. 01.050

Diaci J, Rozenbergar D, Anic I, Mikac S, Saniga M, Kucbel S, Visnjic C, Ballian D (2011). Structural dynamics and synchronous silver fir decline in mixed old-growth mountain forests in Eastern and Southeastern Europe. Forestry 84: 479-491. - doi: 10.1093/forestry/cpro30

Didion M, Kupferschmid AD, Wolf A, Bugmann H (2011). Ungulate herbivory modifies the effects of climate change on mountain forests. Climatic Change 109: 647-669. - doi: 10.1007/s1058 4-011-0054-4

Dobrowolska D, Veblen TT (2008). Treefall-gap structure and regeneration in mixed Abies alba stands in central Poland. Forest Ecology and Management 255: 3469-3476. - doi: 10.1016/j.for eco.2008.02.025

Ellenberg H (1996). Vegetation Mitteleuropas mit den Alpen in ökologischer, dynamischer und historischer Sicht [Vegetation of Central Europe with the Alps in ecological, dynamic and historical view]. Verlag Eugen Ulmer, Stuttgart, Germany, pp. 1357.

Ficko A, Poljanec A, Bončina A (2011). Do changes in spatial distribution, structure and abundance of silver fir (Abies alba Mill.) indicate its decline? Forest Ecology and Management 261: 844-854. - doi: 10.1016/j.foreco.2010.12.014

Ficko A, Roessiger J, Bončina A (2016). Can the use of continuous cover forestry alone maintain silver fir (Abies alba Mill.) in central European mountain forests? Forestry 89: 412-421. doi: 10.1093/forestry/cpw013

Gayer K (1886). Der gemischte Wald: seine Begründung und Pflege, insbesondere durch Horst- und Gruppenwirtschaft [The mixed forest: its foundation and tending, especially by shelterwood and group selection systems]. Paul Parey, Berlin, Germany, pp. 168.

Gill RMA (2006). The influence of large herbivores on tree recruitment and forest dynamics. In: "The impact of Large Mammalian Herbivores on Biodiversity, Ecosystem structure and Function" (Danell K, Bergstrom R, Rooke T eds). Cambridge University Press, Cambridge, UK, pp. 170-202.

Griess V, Knoke T (2013). Bioeconomic modeling of mixed Norway spruce - European beech stands: economic consequences of considering ecological effects. European Journal of Forest Research 132: 511-522. - doi: 10.1007/s10342-0130692-3

Holopainen M, Vastaranta M, Hyyppä J (2014). Outlook for the next generation's precision forestry in Finland. Forests 5: 1682-1694. - doi: $10.3390 / f_{5071682}$

Hyytiäinen K, Haight RG (2010). Evaluation of forest management systems under risk of wildfire. European Journal of Forest Research 129: 909919. - doi: 10.1007/s10342-009-0278-2

Jerina K (2009). Vplivi velikih rastlinojedih parkljarjev na populacijsko dinamiko jelke: kaj o njih vemo ali pa bi morali še spoznati za boljše upravljanje? [The influence of large ungulates on the population dynamics of silver fir: what 
we know about it or we should know about it for better management]. University of Ljubljana, Biotechnical Faculty, Department of Forestry and Renewable Forest Resources, Slovenia, Website. [in Slovenian] [online] URL: http:// web.bf.uni-lj.si/go/gsd2009/predstavitve/Vplivv elikihrastlinojedihparklarjevnapopulacijskodina mikojelke.pdf

Kamler J, Dobrovolny L, Drimaj J, Kadavy J, Kneifl M, Adamec Z, Knott R, Martiník A, Plhal R, Zeman J, Hrbek J (2016). The impact of seed predation and browsing on natural sessile oak regeneration under different light conditions in an over-aged coppice stand. iForest - Biogeosciences and Forestry 9: 569-576. - doi: 10.3832/ ifor1835-009

Klopčič M, Jerina K, Bončina A (2010). Long-term changes of structure and tree species composition in Dinaric uneven-aged forests: are red deer an important factor? European Journal of Forest Research 129: 277-288. - doi: 10.1007/s10 342-009-0325-z

Kramer K, Bruinderink G, Prins HHT (2006). Spatial interactions between ungulate herbivory and forest management. Forest Ecology and Management 226: 238-247. - doi: 10.1016/j.for eco.2006.01.037

Kuijper DPJ, Cromsigt J, Churski M, Adam B, Jedrzejewska B, Jedrzejewski W (2009). Do ungulates preferentially feed in forest gaps in European temperate forest? Forest Ecology and Management 258: 1528-1535. - doi: 10.1016/j. foreco.2009.07.010

Kupferschmid AD, Zimmermann S, Bugmann H (2013). Browsing regime and growth response of naturally regenerated Abies alba saplings along light gradients. Forest Ecology and Management 310: 393-404. - doi: 10.1016/j.foreco.20 13.08 .048

Lafond V, Lagarrigues G, Cordonnier T, Courbaud $B$ (2014). Uneven-aged management options to promote forest resilience for climate change adaptation: effects of group selection and harvesting intensity. Annals of Forest Science 71: 173-186. - doi: 10.1007/s13595-013-0291-y

Lindo Systems Inc (2012). "What's Best" (version 12.0.1.5). Excel add-in for linear, non-linear, and integer modeling. Lindo Systems Inc., Chicago, USA.

López Torres I, Ortuno Pérez S, García Robredo F, Fullana Belda C (2016). Optimizing the management of uneven-aged Pinus nigra stands between two stable positions. iForest - Biogeosciences and Forestry 9: 599-607. - doi: 10.3832/ ifor1298-008

Manso R, Pukkala T, Pardos M, Miina J, Calama R (2014). Modelling Pinus pinea forest management to attain natural regeneration under present and future climatic scenarios. Canadian Journal of Forest Research 44: 250-262. - doi: 10.1139/cjfr-2013-0179

Mathews JD (1999). Silvicultural systems. Oxford University Press, New York, USA, pp. 284.

Miina J, Pukkala T, Hotanen JP, Salo K (2010). Optimizing the joint production of timber and bilberries. Forest Ecology and Management 259: 2065-2071. - doi: 10.1016/j.foreco.2010.02. 017

Miller BF, Campbell TA, Laseter BR, Ford WM, Miller KV (2009). White-tailed deer herbivory and timber harvesting rates: Implications for regeneration success. Forest Ecology and Management 258: 1067-1072. - doi: 10.1016/j.foreco. 2009.05.025

Milner JM, Bonenfant C, Mysterud A, Gaillard JM, Csányi S, Stenseth NC (2006). Temporal and spatial development of red deer harvesting in Europe: biological and cultural factors. Journal of Applied Ecology 43: 721-734. - doi: 10.1111/j. 1365-2664.2006.01183.x

Möst L, Hothorn T, Möller J, Heurich M (2015). Creating a landscape of management: Unintended effects on the variation of browsing pressure in a national park. Forest Ecology and Management 338: 46-56. - doi: 10.1016/j.foreco. 2014.11.015

Muscolo A, Settineri G, Bagnato S, Mercurio R, Sidari M (2017). Use of canopy gap openings to restore coniferous stands in Mediterranean environment. iForest - Biogeosciences and For estry 10: 322-327. - doi: 10.3832/ifor1983-009

Pendergast TH, Hanlon SM, Long ZM, Royo AA, Carson WP (2016). The legacy of deer overabundance: long-term delays in herbaceous understory recovery. Canadian Journal of Forest Research 46: 362-369. - doi: 10.1139/cjfr2015-0280

Pukkala T (2015). Optimizing continuous cover management of boreal forest when timber prices and tree growth are stochastic. Forest Ecosystems 6 (2): 1-13. - doi: 10.1186/s40663-0150028-5

Rämö J, Tahvonen O (2014). Economics of harvesting uneven-aged forest stands in Fenno- scandia. Scandinavian Journal of Forest Research 29: 777-792. - doi: 10.1080/02827581.201 4.982166

Reimoser F, Gossov H (1996). Impact of ungulates on forest vegetation and its dependence on the silvicultural system. Forest Ecology and Management 88: 107-119. - doi: 10.1016/S03781127(96)03816-9

Roessiger J, Ficko A, Clasen C, Griess VC, Knoke T (2016). Variability in growth of trees in unevenaged stands displays the need for optimizing diversified harvest diameters. European Journal of Forest Research 135: 283-295. - doi: 10.100 7/s10342-015-0935-6

Sage RW, Porter WF, Underwood HB (2003). Windows of opportunity: white-tailed deer and the dynamics of northern hardwood forests of the northeastern US. Journal for Nature Conservation 10: 213-220. - doi: 10.1078/1617-1381-00 021

SFS (2014). Digital logging register 1995-2014. Database Timber.dbf, Slovenian Forest Service, Ljubljana, Slovenia.

SFS (2017). Forest data viewer. Web Site. [online] URL: http://prostor.zgs.gov.si/pregledo valnik/?locale=en

Stancioiu P, O'Hara K (2006). Regeneration growth in different light environments of mixed species, multiaged, mountainous forests of Romania. European Journal of Forest Research 125: 151-162. - doi: 10.1007/s10342-005-0069-3

Stergar M, Jonozovič M, Jerina K (2009). Distribution and relative densities of autochthonous ungulates in Slovenia. Gozdarski vestnik 67: 376-380.

Tanentzap AJ, Bazely DR, Koh S, Timciska M, Haggith EG, Carleton TJ, Coomes DA (2011). Seeing the forest for the deer: do reductions in deer-disturbance lead to forest recovery? Biological Conservation 144: 376-382. - doi: 10.1016/ j.biocon.2010.09.015

Tremblay J-P, Huot J, Potvin F (2007). Densityrelated effects of deer browsing on the regeneration dynamics of boreal forests. Journal of Applied Ecology 44: 552-562. - doi: 10.1111/j.13652664.2007.01290.x

Wagner S, Fischer H, Huth F (2011). Canopy effects on vegetation caused by harvesting and regeneration treatments. European Journal of Forest Research 130: 17-40. - doi: 10.1007/s103 42-010-0378-z 